\title{
Exploration and Practice of Construction of Tutorship-oriented Entrepreneurship Space in University -Taking Xi'an Fanyi University as an Example
}

\author{
Jun Zheng, Goufang Kou \\ Xi’an Fanyi University, Xi’an, Shaanxi Province, China, 710105
}

Keywords: construction of entrepreneurship education system; construction of entrepreneurship Space; practice and exploration

\begin{abstract}
With innovation-driven development strategy implemented by government and urgent increasing demand for the promotion of efficiency upgraded in economy in recent years, as the main position to output top talents, colleges and universities are with primarily duty bound to shoulder the responsibilities for building innovation and entrepreneurship education system and fostering innovative spirit of faculty and students and cultivating their entrepreneurial skills; in order to create favorable atmosphere for innovation and entrepreneurship, colleges and universities have set up entrepreneurship and incubation parks for college students (Entrepreneurship Space) in succession, the paper takes construction and practice of Entrepreneurship Space of Xi'an Fanyi University as an example to elaborate the building of entrepreneurship education system as well as management, operation, faculty improvement and fundraising for Entrepreneurship Space to offer reference for similar local colleges and universities to carry out training on how to build tutorship-oriented entrepreneurship incubation parks.
\end{abstract}

\section{Introduction}

The 18th National Congress of the Communist Party of China has carried out an important deployment on training of talents for innovation and entrepreneurship and the State Council has blown the horn of "Mass Entrepreneurship and Innovation", national leaders required improvement in innovation and entrepreneurship education and put forward definite requirement thereof in many conferences, China has also sped up the pace into innovation oriented society and the time for mass entrepreneurship has arrived. With innovation driven development strategy implemented by government and urgent demand for promotion of efficiency increase and upgrade in economy, the constant development of innovation and entrepreneurship in college or university has not only been favorable for integrated reform of higher education but also inspired college students' enthusiasm for entrepreneurship and employment with high quality. An increasing number of carriers (entrepreneurship entity) to accommodate "settlement" of innovation and entrepreneurship education have been established in college or university in the form of Science and Technology Park (incubator), Entrepreneurship Space (entrepreneurship incubation base), industry-academy and research base and innovation center. Every college or university have accelerated the pace for reform of innovation and entrepreneurship education to support incubation of entrepreneurship project by college students driven by campaigns including "National Internet +" College Students Innovation and entrepreneurship Competition and College Students Innovation and entrepreneurship Training Program so as to further promote their service for local economy and upgrade professional education and employment quality.

\section{Training of Tutorship-oriented Entrepreneurship Space}

Entrepreneurship Space for Creative Translation in Xi'an Fanyi University was set up in 2015, covering an area of 3000sqm, equipped with common facilities including coffee house for entrepreneurship, road show hall for entrepreneurship and practice space for entrepreneurship, 100 work positions, several conference rooms, training rooms, gratuitous office space, investment 
connection, on line service, entrepreneurship consultation, entrepreneurship training, entrepreneurship exhibition etc. Entrepreneurship Space accommodates 50 entrepreneurship teams and enterprises all the year round, having teaching and research office for entrepreneurship, management office for entrepreneurship and incubation project, training center and entrepreneurship development center, with more than 6000 students subjected to training and tutoring for entrepreneurship in the base depending on educational resource superiority every year.

\section{The Building of Entrepreneurship Education System}

Since training of tutorship oriented Entrepreneurship Space and building of entrepreneurship education system is the cornerstone for long term development of such Entrepreneurship Space.

One "platform": Based on homogenization of Entrepreneurship Space (incubation base) built in college and university, every college or university should properly position their incubation base according to their featured specialty or certain distinctive project in regional service to build a corresponding teamwork platform to offer an integrated service for entrepreneurship and innovation characterized by close cooperation among government, enterprise and college or university and resource sharing so as to occupy the commanding height of the industry and sector. Entrepreneurship Space for Creative Translation is the banner of "Building of Cross-Border E-commerce and Culture Innovation Incubation Base" put forward based on foreign language specialty and regional position of Xi'an as a starting point of "Belt and Road" in strategy so as to strive for high quality resource and preferential policy from government and society and try to become a training agency and Entrepreneurship Space (entrepreneurship and innovation base) designated by Provincial (Municipal) Department of Human Resource and Social Security and Department of Science and Technology and Department of Commerce and open the channel for government or enterprise to offer entrepreneurship policy and fund to support project and college or university is to offer ground and infrastructure and complete subsequent connection between students and incubation park by government after their graduation, with definite social responsibilities that government is to define policy and enterprise is to offer fund and college or university is to foster talent to achieve that three parties are to convoy college or university students entrepreneurship.

Two "mode" : Mr. Ding Zuyi as the founder of the University took the lead in proposing the training mode of application and innovation oriented talents integrating "foreign language + specialty + modern skill" and "specialty + foreign language + modern skill", namely it is necessary for foreign language majors to take international commerce, financial management, software engineering, e-commerce as elective courses for their second major and relevant professional skill in addition to foreign language courses and it is advisable for other majors to take English, Japanese and German as elective courses for their second major and relevant professional skill in addition to their major courses. In addition, every student in college or university should carry out social investigation for four times and prepare investigation reports and take no less than three courses for entrepreneurship basis (marketing). Students under the guidance of major teacher have improved their abilities to analyze and innovate future market in their major. The connotation of such training mode for talents today also offers favorable innovation soil for training of innovation oriented talents.

Three "layers": Entrepreneurship (education) put forward by Mr. Li Jiahua as an entrepreneurship educator should be the viewpoint on initiation in school work, career and enterprise. The college or university may carry out stratified education on students, namely to carry out education of initiation in school work on students, with focus on training of students innovation awareness to make students analyze their actuality based on their majors and strong point and interest so as to learn their interested courses and improve their innovation abilities therein. Second layer is initiation of career, after students have pioneering awareness, it is advisable to encourage them to implant their ideal into real life to make an investigation of the problems in society and environment in which they are living so as to look for the road to their growth and career to achieve personal value in problem finding and solving process, showing that they are willing to participate 
in professional activity, social interaction, practice and investigation and public welfare undertakings etc. The final layer is initiation of enterprise, when part of able students with spirit of adventure and entrepreneurial ability as well as social experience and social resource are likely to initiate an enterprise when they face proper opportunity.

Five "modules": According to the above mentioned conception of stratified entrepreneurship education, entrepreneurship education is also divided into five training modules, such as training of spirit of innovation and theoretical knowledge on entrepreneurship, practice and investigation of innovation and entrepreneurship, training of entrepreneurial ability and practice in initiation of enterprise for students. The five modules are in two education stages, namely, universal education stage for all students including training of spirit of innovation and theoretical knowledge on entrepreneurship and practice and investigation of innovation and entrepreneurship and professional education stage including training of entrepreneurial ability and practice in initiation of enterprise for partial students arranged in Entrepreneurship Space for entrepreneurship. It is adequate for a majority of students to learn the first three modules and some students with intense intention of entrepreneurship are subjected to training given in remaining two modules.

\section{Management and Operation of Entrepreneurship Space}

There are primary four types of projects settled in Entrepreneurship Space for Creative Translation: project for innovation and practice by college or university students, planned project for innovation and entrepreneurship by college or university students, project for entrepreneurship entity by college or university students and project for enterprise registration, which are different in operation mechanism.

Planned project for innovation and entrepreneurship by college or university students is an activity for excellent entrepreneurship training and practice project in national and provincial innovation and entrepreneurship training plan approved for college or university students to settle in the park. Applicant should obtain national or provincial approval to set up project and then submit an application for settlement to entrepreneurship base to make a research (incubation) for one or two years (to be determined according to the time of completion of project), after expiration, the achievement should be submitted for market operation.

Project for innovation and practice by college or university students is that applicant is to set up his or her entrepreneurship team and implement project based on his or her interest in science and technology and discipline competition project. Applicant is to organize his or her team and submit an application to entrepreneurship base, after examination, the project is to subject to research and training for two or four years to achieve rolling development based on recruitment and elimination every year. In case that member in team has mature project, he or she may leave the team for independent market operation.

Project for entrepreneurship entity by college or university students is to offer an environment for entrepreneurship for entrepreneurship project without registered company so as to prepare for incubation and marketing. Applicant is to set up team and submit an application, after review, the project is to subject to incubation for two years, before expiration and leaving, the project is to subject to industrial and commercial registration to enter into market.

Enterprise project is operation of project with registered company settled in Entrepreneurship Space. Applicant is company registered in industrial and commercial department, it is necessary for it to submit an application to entrepreneurship, after review, the project is to settle for steady development for two years, after expiration, it may quit or be recommended to incubation park by government.

\section{Preparation for Venture Capital Pool}

\subsection{To set up venture fund for colleges and universities}

In order to inspire teachers and students enthusiasm for entrepreneurship, the university is to 
allocate a special fund from RMB 200,000 yuan to RMB 300,000 yuan to support activities for innovation and entrepreneurship by students every year. The entrepreneurship project applied for by student is to obtain subsidy from RMB 3000 yuan to RMB 10000 yuan on the premise of being reviewed by expert committee of the university.

\subsection{To set up alumni (entrepreneurship) fund}

Shanghai Alumni Foundation of Xi'an Fanyi University was established, which was declared in Shanghai Alumni Conference of Xi'an Fanyi University held in Shanghai Jianguo Hotel in 2015, aiming to assist alumni for entrepreneurship. In addition, "Ding Zuyi” Education Foundation also indicated a plan to allocate RMB 1 million yuan to subsidize students' entrepreneurship, which was actively followed by alumni associations in various regions, with entrepreneurship foundations set up in succession to subsidy alumni for entrepreneurship.

To strive for policy fund support, it is advisable to pay attention to preferential policy on entrepreneurship defined by provincial and municipal department of human resource and social security to assist students to obtain start-up loan in YBC and small-sum guaranteed loan for entrepreneurship and employment in Shaanxi Province and venture capital fund for graduates from college or university in Shaanxi Province and start-up loan for college or university students in Xi'an.

Venture capital fund from social enterprise and venture capital institution and reward fund from venture based competition. It is advisable to attract social resources such as JD Crowdfunding and “To Youth” Public Welfare Project Fund for Entrepreneurship by College Students, Incubation Fund of Xi'an International Trade \& Logistics Park and encourage students to participate in various venture based competitions so as to get the attention from Angel and Venture Investment etc.

\section{The Building of Teaching Staff for Entrepreneurship by Internal and External Improvement}

In order to improve teaching and academic level of teachers in entrepreneurship education, the university has set up "Teaching and Research Office for Entrepreneurship Education” TO allocate special fund to subsidize teachers to take the courses for entrepreneurship education by KAB and DMC and initiated compilation of textbook for courses in entrepreneurship and innovation, preparation for curriculum and teacher resources. In addition, it is advisable to cooperate with YBC and Xi'an Entrepreneurship Training Base for College Students and recruit entrepreneurs, alumni successful in entrepreneurship and famous experts for innovation and entrepreneurship to serve as Advisor for Entrepreneurship" to offer guidance and consultation in the process of practice by students. A full-time and part-time teaching staff with profound theory and high ability to guide innovation and entrepreneurship is taking shape.

\section{Conclusion}

After almost three years of operation and development, Entrepreneurship Space for Creative Translation has become National Entrepreneurship Space, Designated Agency for Training of Entrepreneurship and Employment for College Students in Shaanxi Province, Youth Entrepreneurship Training Base, Service Station for Entrepreneurship by College Students and Entrepreneurship Incubation Base in Xi'an, with more than 2000 persons trained for entrepreneurship entrusted by Provincial and Municipal Departments of Human Resource and Social Security and more than 1000 training and education activities for entrepreneurship covering students up to 4000 person times, having obtained more than 100 national and provincial awards for innovation and entrepreneurship and more than 20 enterprises incubated, in which, the entrepreneurship project of "Pretty Car Every Day" having won gold award in Shaanxi Competition Zone of "National First Internet + College Student Innovation and Entrepreneurship has financed RMB 5 million yuan with the aid of platforms of government, enterprise and university to enter into market without a hitch and having achieved considerable market return. 
In the ascendant waves of national innovation and entrepreneurship education, college or university is greeting unprecedented opportunities and challenges. Innovation and entrepreneurship education is certain to become a key business card for "Double First-Class Universities" in various regions to show their charm and promote college or university to become a hard core for regional economy and social development.

\section{Acknowledgement}

This research was financially supported by: 1) Project of Science and Technology Bureau, Chang'an District, Xi'an: A Study on ChuangYi Inclubation Base of Xi'an Fanyi University (Project No.CC1702) 2) The Special Project of Xi'an Social Science Fund: Reform of Innovation and Entrepreneurship Education in Applied Universities in Xi'an under the Background of Internet + (Project No.16XF12)

\section{References}

[1] Hanfang Chu, Yankong Zhu. Construction and exploration of college students' Entrepreneurial incubation park [J]. Experimental Technology and Management, 2015.48:50

[2] Yifan Zeng. Discussion on the Operation Model of Undergraduate Entrepreneurial Incubation Base [J]. Journal of Beijing Economic Management Vocational College, 2016.03

[3] Fen Zhang. The evaluation of college students' entrepreneurship incubator base in Suzhou vocational colleges with social benefit evaluation [J]. Education and Occupation,2015.26

[4] Tong Yu. Research on the Development of Undergraduate Entrepreneurship Incubation Base [J]. Journal of Baicheng Education University, 2017.10 